\title{
Evaluation of Wilt Resistance of Wild Solanum Species through Grafting in Brinjal
}

\author{
B. Ashok Kumar ${ }^{1 *}$, P. Raja ${ }^{2}$, A.K. Pandey ${ }^{3}$ and P. Rabindro ${ }^{1}$ \\ ${ }^{1}$ Bidhan Chandra Krishi Vishwavidyalaya (BCKV), PhD Scholar, Department Vegetable crops, \\ Mohanpur, West Bengal-741252, India \\ ${ }^{2}$ College of Horticulture and Forestry, Department of Plant Pathology, (CAU) Pasighat, \\ Arunachal Pradesh-791102, India \\ ${ }^{3}$ College of Horticulture and Forestry, Dean, Department of Vegetable Science (CAU) Pasighat, \\ Arunachal Pradesh-791102, India \\ *Corresponding author
}

A B S T R A C T

\begin{abstract}
Keywords
Eggplant genotypes, Grafting, Bacterial wilt, Solanum species, Graft compatibility.

Article Info

Accepted:

10 July 2017

Available Online:

10 September 2017 rootstocks against bacterial wilt and to evaluate graft compatibility of eggplant varieties with Solanum rootstocks. The experiment was laid out in Complete Randomized Design (CRD) with four replications. Bacterial wilt is one of the major problems in production of brinjal in North Eastern hill regions. The four Solanum species and two varieties were screened against bacterial wilt, among all Solanum speciesi.e. Solanum torvum and Solanum khasianum found resistant but remaining Solanum species and cultivated genotypes i.e. Pusa Shyamala and Pusa Hybrid-6 were found susceptible. The highest graft compatibility observed in plants grafted with Solanum torvum followed by Solanum surathense. The data recorded regarding the percent of bacterial wilt infection varied with rootstock used in grafting. The highest infection rate was observed in non-grafted plants $(71.35 \%)$ followed by Solanum surathense $\times$ Pusa Shyamala $(58.525 \%)$. The lowest infection rate was recorded in Solanum torvum $\times$ Pusa Shyamala (12.22\%). Based on mean performance of the grafted plants with Solanum torvum and Solanum khasianum were found to be superior and they can be used for resistance against soil borne bacteria.
\end{abstract}

The grafting in eggplant was carried out to obtain resistance sources among Solanum

\section{Introduction}

Eggplant (Solanum melongena L.) belongs to the family Solanaceae. India is the world's second largest producer with 7.22 lack hectare areaand 13 lack tonnes production annually (NHB, 2013-14), accounting nearly $26 \%$ of global production. The West Bengal is leading producer of brinjal and it contributes $22 \%$ of total country production (NHB, 2013$14)$. The yield is very low due to numerous diseases and parasites, in particular to
Ralstonia solanacearum, Fusarium wilt, Verticellium wilt and Bacterial wilt, nematodes and several insect pests (Collonnier et al., 2001).Among all, bacterial wilt is extreme disease expressed rapid wilting by yellowing of foliage followed by collapse of entire plant. Soil treatment with chemicals and resistant sources were used so far but due to residual nature of chemicals only alternative left is resistant sources. The 
number of wild relatives of Solanum species was resistant and graft compatible to eggplant. Grafting of vegetable crops is a simple method of propagation in which preferred rootstocks are used to improve vigour, precocity, enhanced yield and quality, better survival under abiotic and biotic stress conditions (Pandey and Rai, 2003). To get maximum success of grafting selection of rootstock resistant to wilt is necessary. However, to get positive effect of grafting on vegetable quality, rootstock/scion combinations should be necessary for specific climatic and geographic situations (Davis et al., 2008).It is difficult for farmers to provide intensive care required to raise newly grafted plants, often requiring the added cost of a transplant facility that has healing chambers and trained personnel. Concerning above problems the present investigation was undertaken to evaluate the graft compatibility among wild Solanum rootstocks onto cultivated eggplant genotypes and to identify resistant rootstocks against bacterial wilt.

\section{Materials and Methods}

The field experiments were carried out in experimental farm, Department of Vegetable Science, College of Horticulture and Forestry, CAU, Pasighat, Arunachal Pradesh during August, 2014 to assess the wild Solanum species and cultivated eggplant genotypes against bacterial wilt and to know the graft compatibility of Solanum species as a rootstocks. The experiment was laid out in Complete Randomized Design (CRD) with four replications.

\section{Experiment-1: Evaluation of wild Solanum species and eggplant genotypes against bacterial wilt}

The experimental materials for present study comprised of four wild Solanum species and two eggplant genotypes grown in nursery

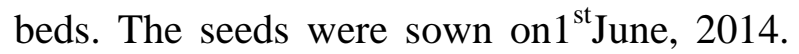
Before sowing, seeds were treated with $\mathrm{GA}_{3}$ solution (100ppm) for $24 \mathrm{hrs}$ at room temperature for quick germination. The fifteen days old seedlings were transferred to plastic trays containing mixture of sand and farm yard manure. For inoculation, the pathogen was isolated from roots and stems of diseased eggplant by serial dilution method and incubated in Petriplates to obtain pure culture of bacteria. The 10 day's old bacterial colonies were selected for further multiplication in nutrient agar medium using streak plate method. The obtained pure culture from mixture of different bacteria, selected a well isolated colony from each plate and recorded their features. The well isolated colony from each plate was selected from pure bacterial culture. The spore suspension prepared by scraping the surface of 10 days old growth on agar plate. The $5 \times 10^{5}$ spores $/ \mathrm{ml}$ of diluted spore suspension was prepared with help of Haemocytometer. The spore suspension was applied near root zone of plants by making damage to the root system. After inoculation, pots were kept inside the inoculation chamber where sufficient relative humidity and optimum temperatures were maintained.

The disease incident was calculated using PDI formula

The Percent Disease Incidence (PDI) = Number of infected plants / total number of plants observed $\times 100$

Experiment-2: Graft compatibility of wild Solanum species on cultivated eggplant genotypes

The experimental materials for the present study comprised of four wild Solanum species namely Solanum torvum, Solanum xanthocarpum, Solanum khasianum and Solanum surathense and two eggplant 
genotypes i.e. Pusa Shyamala and Pusa Hybrid-6. The seeds of wild Solanum species were sown on $1^{\text {st }}$ June, 2014 and seeds of eggplant genotypes were sown on $10^{\text {th }}$ June, 2014 in plastic trays containing sandy soil. Ten daysbefore sowing, seeds were treated with $\mathrm{GA}_{3}$ solution (100ppm) for $24 \mathrm{hrs}$ at room temperature for quick germination. The fifteen days old seedlings were transferred to plastic trays containing mixture of sand and farm yard manure.

Forty to fifty days old rootstock seedlings (45 leaf stage) and seedlings of eggplant varieties at 3-4 leaf stage were grafted. All plants were grafted by cleft method of grafting (Johnson et al., 2011; Lee and Oda, 2003).The number of plantlets with successful grafting was recorded ten and thirty days after grafting (DAG).

\section{Experiment-3: Evaluation of grafted plants against bacterial wilt}

For inoculum, freshly isolated pathogen from pure culture was selected and spore suspension was prepared by diluting $5 \times 10^{5}$ spores $/ \mathrm{ml}$ of water with help of Haemocytometer.

The adequate $2 \mathrm{ml}$ of spore suspension was applied near root zone of plants by making damage to the root system. The minimum 10 number of grafted plants from each combination were selected for inoculation and allowed to grow one month by adopting normal package of practices. After inoculation, the pots were kept inside the inoculation chamber where sufficient relative humidity and optimum temperatures were maintained.

\section{Statistical analysis}

The data obtained were analyzed by using the analysis of variance for Completely Randomised Design (CRD) as described by
Panse and Sukhatme (1985) with four replications consisting of 3 plants. The level of significance used in F-test was 0.05 and critical difference (CD) values were calculated whenever the F-test was significant.

\section{Results and Discussion}

Experiment-1: Evaluation of wild Solanum species and eggplant genotypes against bacterial wilt

The data recorded in table 1 shows that all non-grafted eggplant genotypes i.e. Pusa Shyamala, Pusa Hybrid-6 were found susceptible to bacterial wilt. Among four wild Solanum species Solanum torvum (5.708\%) gave resistant reaction and Solanum khasianum (15.825) moderately resistant to bacterial wilt and remaining Solanum xanthocarpum and Solanum surathense were found susceptible.

Similar reports of wilt resistance sources among Solanum species were found by Singh and Gopalakrishna (1997), Lee and oda (2003).

Experiment-2: Graft compatibility of wild Solanum species on cultivated eggplant genotypes

The graft compatibility study in table 2 shows that among all graft combinations Pusa Hybrid-6 onto Solanum torvum rootstock noted highest survival rate $(81.85 \%$ 10DAG $\& 67.35 \%$ 30DAG) followed by Pusa Shyamala with Solanum torvum $(78.625 \%$ 10DAG \&66.57\% 30DAG) compared to all other graft combinations. The lowest survival rate was observed in Solanum xanthocarpum (30.02\% 30DAG) when grafted with Pusa Shyamala. Highest survival rate of grafted plants using Solanum torvum rootstock was in contrast with the observations of Petron and Hoover (2014). 
Table.1 Response of wild Solanum species and eggplant genotypes/varieties against Bacterial wilt

\begin{tabular}{|l|c|c|}
\hline Wild Solanum species and eggplant genotypes & \% wilt infection & Grading \\
\hline Solanum torvum & 5.768 & $\mathrm{R}$ \\
\hline Solanum Xanthocarpum & 46.125 & $\mathrm{~S}$ \\
\hline Solanum khasianum & 15.825 & $\mathrm{MR}$ \\
\hline Solanum surathense & 54.475 & $\mathrm{~S}$ \\
\hline Pusa Shyamala & 72.175 & $\mathrm{~S}$ \\
\hline Pusa Hybrid-6 & 68.375 & $\mathrm{~S}$ \\
\hline C.D. & 2.503 & \\
\hline SE(m) & 0.836 & \\
\hline SE(d) & 1.182 & \\
\hline C.V. & 3.819 & \\
\hline
\end{tabular}

R- Resistance, S- Susceptibility, MR- Moderately resistance, \%- Percentage

Table.2 Effect of different wild Solanum species as a rootstocks on survival rate of grafted Eggplant genotypes

\begin{tabular}{|l|c|c|}
\hline Grafting combinations & Survival Rate 10 DAG (\%) & Survival Rate 30 DAG (\%) \\
\hline Solanum torvum $\times$ Pusa Shyamala & 78.625 & 66.575 \\
\hline Solanum torvum $\times$ Pusa Hybrid-6 & 81.850 & 67.350 \\
\hline Solanum xanthocarpum $\times$ Pusa Shyamala & 40.025 & 30.025 \\
\hline Solanum xanthocarpum $\times$ Pusa Hybrid-6 & 39.875 & 30.150 \\
\hline Solanum khasianum $\times$ Pusa Shyamala & 61.125 & 40.300 \\
\hline Solanum khasianum $\times$ Pusa Hybrid-6 & 59.375 & 39.225 \\
\hline Solanum surathense $\times$ Pusa Shyamala & 52.825 & 53.500 \\
\hline Solanum surathense $\times$ Pusa Hybrid-6 & 51.900 & 49.675 \\
\hline C.D. & 4.027 & 4.534 \\
\hline SE(m) & 1.372 & 1.544 \\
\hline SE(d) & 1.940 & 2.184 \\
\hline C.V. & 4.713 & 6.557 \\
\hline
\end{tabular}

DAG- Days after grafting, \%- Percentage

Table.3 Effect of different wild Solanum species on percent bacterial wilt infection of Grafted plants

\begin{tabular}{|l|c|l|}
\hline Grafting combinations & Bacterial wilt infection (\%) & Grading \\
\hline Solanum torvum $\times$ Pusa Shyamala & 12.225 & $\mathrm{R}$ \\
\hline Solanum torvum $\times$ Pusa Hybrid-6 & 13.475 & $\mathrm{R}$ \\
\hline Solanum xanthocarpum $\times$ Pusa Shyamala & 45.500 & $\mathrm{~S}$ \\
\hline Solanum xanthocarpum $\times$ Pusa Hybrid-6 & 48.175 & $\mathrm{~S}$ \\
\hline Solanum khasianum $\times$ Pusa Shyamala & 29.600 & $\mathrm{MR}$ \\
\hline Solanum khasianum $\times$ Pusa Hybrid-6 & 31.475 & $\mathrm{MR}$ \\
\hline Solanum surathense $\times$ Pusa Shyamala & 58.525 & $\mathrm{~S}$ \\
\hline Solanum surathense $\times$ Pusa Hybrid-6 & 55.300 & $\mathrm{~S}$ \\
\hline Control plants & 71.350 & $\mathrm{~S}$ \\
\hline C.D. & 2.361 & \\
\hline SE(m) & 0.809 & \\
\hline SE $(\mathbf{d})$ & 1.145 & \\
\hline C.V. & 3.985 & \\
\hline
\end{tabular}

R- Resistance, S- Susceptibility, MR- Moderately resistance, \%- Percentage 
Experiment-3: Evaluation of grafted plants against bacterial wilt

It is evident from results that grafted plants showed resistance and the non-grafted plants showed vulnerability against bacterial wilt disease. Among grafted and non-grafted plants, the highest percentage of wilt infection observed in non-grafted plants. The Highest infection was observed in non-grafted plants (90.9\%) followed by Pusa Shyamala grafted with Solanum surathense (58.52\%). The plants grafted with solanum torvum showed resistance reaction followed by moderate resistance reaction observed in plants grafted with Solanum khasianum against bacterial wilt infection. The similar results of solanum torvum as resistant rootstock against bacterial wilt was observed by Ali (1993); (Rahman et al., 2002).The maximum resistance against bacterial wilt was observed in Solanum torvum followed by Solanum Khasianum. Superiority of Solanum torvum rootstock against bacterial wilt infestation caused by Ralstonia solanacearum may be observed inline of the work concluded by Aribaud et al., (2014) who observed, an increased cell wall mono amine oxidase activity in Solanum torvum after Ralstonia solanacearum inoculation (Table 3).

Among all rootstocks used ingrafting, Solanum torvum was found best rootstock followed by Solanum khasianumand promising for resistance towards bacterial wilt. Whereas Solanum surathense and Solanum xanthocarpum showed maximum susceptible reaction against bacterial wilt infection among all grafted plants. The nongrafted control plants showed highly susceptible compare to grafted ones. The results recommended that eggplant could be grafted on Solanum torvum and Solanum khasianum for graft compatibility controlling bacterial wilt. However, Further refinement of the technology is require particularly in respect of age of rootstocks and scion seedlings and the management of grafted seedlings immediately after grafting.

\section{References}

Ali, M., 1993. Workshop on research and development of vegetable crops. IPSCA-JICA, Gaziabad.

Aribaud, M., Noirot, M., B.S. Fock, and Kodja, H. 2014. Comparison between Solanum torvum SW. and Solanum melongena L. after Ralstonia solanacearum inoculation. Plant Biol (Stuttg). 16(5):1025-8.

Collonnier, C., Fock, I., Kashyap, V., Rotino, G.L., Daunay, M.C., Lian, Y., Mariska, I.K., Rajam, M.V., Servaes, A., X, G. Ducreu and Sihachakr, D. 2001. Applications of biotechnology in eggplant. Plant Cell, Tissue and Organ Culture. 65: 91-107.

Davis, A., King, S., Zhang, X., Levi, A., P. Perkins-Veazie and Hassell, R. 2008. Grafting effects on vegetable quality. HortScience. 43(6): 1670-1672.

Indian Horticulture Data Bases, National Horticultural Board. 2014. HQ, Gurgaon, Haryana.

Johnson S., P. Kreiderand Miles C. 2011. Vegetable grafting eggplants and tomatoes, Washington State University, p 4.

Lee, J. M., and Oda, M. 2003. Grafting of herbaceous vegetable and ornamental crops. Horti. Reviews. 28: 61-124.

Pandey, A. K., and Rai, M. 2003. Prospects of grafting in vegetables: an appraisal. Vegetable Science. 30(2): 101-109.

Panse, V. G., and Sukhatme, P. V. 1985. Statistical Methods for Agricultural Workers. Indian Council of Agricultural Reaserch. 359.

Petran, A., and Hoover, E. 2014. Solanum torvum as a compatible rootstock in inter specific tomato grafting. J. of 
Horticulture 1(1): 103.

Biological Sciences. 5(7): 755-757.

Rahman, M. A., Rashid, M. A., Husain, M. M., M. A. Salam and Mason, A. S. M. Singh, P.K., and Gopalakrishna, T.R. 1997. H. 2002. Grafting compatibility of Grafting for wilt resistance and cultivated eggplant varieties with wild Solanum species. Pakistan Journal of productivity in brinjal (Solanum melongena L.). Horticultural Journal. 2 (10):57-64.

\section{How to cite this article:}

Ashok Kumar, B., P. Raja, A.K. Pandey and Rabindro, P. 2017. Evaluation of Wilt Resistance of Wild Solanum Species through Grafting in Brinjal. Int.J.Curr.Microbiol.App.Sci. 6(9): 34643469. doi: https://doi.org/10.20546/ijcmas.2017.609.425 